\title{
The Taxonomy of Operational Risk
}

\subsection{THE CRITERIA OF CLASSIFICATION}

The heterogeneity of operational risk makes it necessary to come up with a system for classifying it and identifying its components. Hubner, Laycock, and Peemoller (2003) argue that one important advance in the rapidly improving understanding of operational risk is that the disaggregation and classification of operational risk is being put on a more rational footing. All efforts to define, analyze, and interpret operational risk are based on endeavors to come up with collections of risk types and the losses associated with these risks. Disaggregation involves separating out the different components of a risk cluster into categories.

\subsubsection{General principles}

The classification of operational losses (resulting from exposure to operational risk) can be approached from three alternative angles: the causes of operational failure, the resulting loss events, and the legal and accounting forms of consequential losses (that is, cause, event, and effect as shown in Figure 4.5). An operational (loss) event is defined by Haubenstock (2004) as "an event due to failed or inadequate processes, people or systems, or exposure to external events that caused, or potentially could have caused, a material loss or adversely impacted stakeholders". The phrase "potentially could have caused" refers to "near-misses". The effects, according to the $\mathrm{BCBS}$, are the direct losses resulting from (i) write-down of assets, (ii) regulatory compliance penalties, (iii) legal payments/settlements, (iv) customer 
restitution, (v) loss of recourse, and (vi) loss of physical assets. Out of these effects, the two that need explaining are customer restitution and loss of recourse (as the others are straightforward). Restitution refers to payments to third parties resulting from operational losses for which the firm is legally responsible. Loss of recourse refers to losses experienced when a third party does not meet its obligations to the firm, provided that the outcome is attributable to an operational event. Moreover, the causal relations between the three levels (causes, events, and effects) are complex and indeterminate.

At first sight, the BCBS's definition is more consistent with the first alternative: it purports to identify the ultimate sources of operational losses by pointing to four broad categories of causes (people, processes, systems, and external events). The problem is that these generic sources of operational risk cannot be linked in a straightforward manner to the general types of loss identified by the BCBS. However, event- and effect-based regulatory classifications also appear in various Basel papers including the Quantitative Impact Study 3. The logical reason for the three dimensions of cause, event, and effect is easy to understand. Every operational risk manager who wants to know how to reduce exposure needs causal disaggregation to identify areas where management actions will have the desired effect (avoiding the cause outright or reducing the influence of the causer on the frequency or severity of the resulting event). An event-based classification makes the operational risk manager's task easier, as losses can be considered to materialize in an event.

Peccia (2003) argues that what is needed is developing a framework for classifying the causes of operational risk, because the usual classification of the causes of operational risk as either system problems or poor controls is unsatisfactory, giving rise to the possibility of misclassification or double counting. A more appropriate schema, he suggests, is the classification of losses by the area of impact on the results, as the ultimate objectives is to explain the volatility of earnings arising from the direct impact of losses on the financial results. Another problem is that the causes and effects of operational events are still commonly confused. Operational risk types, such as human risk and system risk, constitute the cause (not the outcome) of risk, as the latter is the monetary consequence. Peccia concludes that a classification based on causes is prone to errors and misunderstanding.

\subsubsection{The BCBS classification}

The Basel Committee has proposed the categorization of operational risk into manageable units according to regulatory-specified business lines or functional units. This may not be satisfactory for banks because the structure of regulatory business lines for the standardized approach does not 
reflect the way in which banks are structured or managed. With the help of the industry, the BCBS developed a matrix of seven broad categories of loss events that are further broken down into sub-categories and related activity examples. This classification is similar to the typology of hazards used by the insurance industry. Table 5.1 shows a listing of operational loss events with definitions and examples. Here, it is possible to relate event types to departments. For example, litigation and settlements can be

Table 5.1 The BCBS taxonomy of operational loss events

\begin{tabular}{|c|c|c|}
\hline Event & BCBS Definition & Sub-categories/Examples \\
\hline Internal fraud (IF) & $\begin{array}{l}\text { Losses due to acts of fraud } \\
\text { involving at least one } \\
\text { internal party. }\end{array}$ & $\begin{array}{l}\text { - Account take-over and } \\
\text { impersonation } \\
\text { - Bribes and kickbacks } \\
\text { - Forgery } \\
\text { - Credit fraud } \\
\text { - Insider trading (not on firm's } \\
\text { account) } \\
\text { - Malicious destruction and } \\
\text { - Tax nopropriation of assets } \\
\text { - Theft } \\
\text { - Extortion } \\
\text { - Embezzlement } \\
\text { - Robbery } \\
\text { - Intentional mismarking of } \\
\text { - Uosition } \\
\text { transactions }\end{array}$ \\
\hline External fraud (EF) & $\begin{array}{l}\text { Same as internal fraud } \\
\text { except that it is carried } \\
\text { out by an external party. }\end{array}$ & $\begin{array}{l}\text { - Computer hacking } \\
\text { - Theft of information } \\
\text { - Forgery } \\
\text { - Theft }\end{array}$ \\
\hline $\begin{array}{l}\text { Employment practices } \\
\text { and workplace safety } \\
\text { (EPWS) }\end{array}$ & $\begin{array}{l}\text { Losses arising from violations } \\
\text { of employment and health } \\
\text { and safety laws. }\end{array}$ & $\begin{array}{l}\text { - Discrimination } \\
\text { - Compensation and } \\
\text { termination issues } \\
\text { - Health and safety issues } \\
\text { General liability }\end{array}$ \\
\hline $\begin{array}{l}\text { Clients, products and } \\
\text { business practices } \\
\text { (CPBP) }\end{array}$ & $\begin{array}{l}\text { Losses arising from failure to } \\
\text { meet obligations to clients } \\
\text { or from the design of a } \\
\text { product. }\end{array}$ & $\begin{array}{l}\text { - Disputes over advisory } \\
\text { services } \\
\text { - Violation of anti-monopoly } \\
\text { rules and regulations } \\
\text { - Improper trade } \\
\text { - Insider trading on firm's } \\
\text { account }\end{array}$ \\
\hline
\end{tabular}


Table 5.1 (Continued)

\begin{tabular}{|c|c|c|}
\hline Event & BCBS Definition & Sub-categories/Examples \\
\hline & & $\begin{array}{l}\text { - Market manipulation } \\
\text { - Money laundering } \\
\text { - Unlicensed activity } \\
\text { - Product defects } \\
\text { - Exceeding client exposure } \\
\text { limits } \\
\text { - Account churning } \\
\text { - Aggressive sales } \\
\text { - Breach of privacy } \\
\text { - Misuse of confidential } \\
\text { information } \\
\text { - Customer discloser } \\
\text { violations }\end{array}$ \\
\hline $\begin{array}{l}\text { Damage to physical } \\
\text { assets (DPA) }\end{array}$ & $\begin{array}{l}\text { Losses arising from damage } \\
\text { inflicted on physical assets } \\
\text { by a natural disaster or } \\
\text { another event. }\end{array}$ & $\begin{array}{l}\text { - Terrorism } \\
\text { - Vandalism } \\
\text { - Natural disasters }\end{array}$ \\
\hline $\begin{array}{l}\text { Business disruption and } \\
\text { system failures (BDST) }\end{array}$ & $\begin{array}{l}\text { Losses arising from } \\
\text { disruptions to or failures } \\
\text { in systems, } \\
\text { telecommunication and } \\
\text { utilities. }\end{array}$ & $\begin{array}{l}\text { - Hardware } \\
\text { - Software } \\
\text { - Telecommunications } \\
\text { - Utility outage } \\
\text { - Utility Disruption }\end{array}$ \\
\hline $\begin{array}{l}\text { Execution, delivery and } \\
\text { process management } \\
\text { (EDPM) }\end{array}$ & $\begin{array}{l}\text { Losses arising from failed } \\
\text { transaction processing } \\
\text { with counter-parties such } \\
\text { as vendors }\end{array}$ & $\begin{array}{l}\text { - Incorrect client records } \\
\text { - Negligent loss or damage } \\
\text { of client assets } \\
\text { - Unapproved access to } \\
\text { accounts } \\
\text { - Client permissions } \\
\text { - Missing and incomplete } \\
\text { legal documents } \\
\text { - Failed mandatory } \\
\text { reporting obligations } \\
\text { - Inaccurate external reports } \\
\text { Non-client counterparty } \\
\text { disputes } \\
\text { - Accounting errors } \\
\text { - Collateral management } \\
\text { failure } \\
\text { - Data entry, maintenance } \\
\text { or loading error } \\
\text { - Delivery failure } \\
\text { - Miscommunication } \\
\text { - Missed deadlines } \\
\text { - Vendor disputes }\end{array}$ \\
\hline
\end{tabular}


related to the Legal Department, compensation claims can be related to Human Resources, system failures to IT, settlement failures to Treasury, and errors in the books to the Accounts Department.

An alternative classification structure is based on functional units but this is specific to an individual firm. For example, the term "legal department" can be expected to vary between firms according to their history and internal environment. In the same firm, the term may vary between countries in response to local requirements. Yet, there is clear added value in using this classification, as disaggregation empowers and encourages the functions to monitor and manage risk on a structural basis. Moreover, this approach emphasizes the role of the functional units as providers of proactive, rather than reactive, risk management support to the risk owners.

One problem with this classification is that some of the subcategories do not have precise meaning. Take, for example, "fraud", which does not have an exact legal or regulatory meaning. It is used as a generic term to designate a variety of forms of (mostly nonviolent) economic wrongdoing, whose commission constitutes a criminal offence and/or a civil wrong. Examples of fraud are theft, unauthorized withdrawal of money from ATMs, forgery of instruments, false accounting, fraudulent conveyance, and unauthorized trading. One should distinguish between three roles that a bank can play in fraud: perpetrator, vehicle, or victim. Tax fraud and money-laundering offences are common examples of economic crimes committed by banks. Fraud can be committed by banks and employees against clients and counterparties. In this sense, it is misleading to describe fraud as a risk faced by banks. Rather, the bank itself is the source of risk borne by outside parties (from the bank's perspective, it is legal risk). When the bank is a vehicle for fraud, it is not subject to the direct risk of loss, but reputational risk is present. There may be cases where the law reallocates financial risk, forcing banks to bear the loss and compensate the victims on the grounds of contributory negligence or some breach of conduct-of-business standards (for example, failure to cancel a reported stolen card on time, or not checking signatures). In cases where a bank is the victim or the vehicle, fraud can be internal or external. The BCCI, for example, was both the perpetrator (for example, money laundering) and the victim (fraudulent lending, theft, and other practices of its management).

It may also be the case that some important subcategories are missing. For example, should employment practices and workplace safety have a category called "employee offensive odour". This is not a joke. In a recent article in Financial Times, Sanghera (2005) concluded after some research that "dealing with smelly employees in these days of windowless workplaces and cubicles may be one of the biggest management challenges of our time". Indeed, a message on workplace.net says "any one who has an offensive body odour and works with other people who find it offensive is breaching health and safety law guidelines". This issue may lead to 
termination problems and people failure, as the message says that body odor can cause "disruption in the workplace". Sanghera (2005) says explicitly that "barely a month passes without some smell-related dispute hitting the headlines", referring to the "worker from Portsmouth getting sacked because his bosses claim he is too pongy".

\subsubsection{Classification according to causes (sources)}

The classification of operational risk according to the cause (the sources of risk) is consistent with Mestchaian's (2003) suggested decomposition of the BCBS's definition of operational risk. Table 5.2 reports the risk sources, their categories and examples. For instance, external risk includes external fraud (such as external money laundering), natural disasters (such as floods), and non-natural disasters (such as arson). This classification goes beyond the BCBS categories.

Table 5.2 Operational risk by cause

\begin{tabular}{|c|c|c|}
\hline Risk & Category & Examples \\
\hline People Risk & Disclosure-related issues & $\begin{array}{l}\text { - Concealing losses } \\
\text { - Misuse of important information } \\
\text { - Non-disclosure of sensitive issues }\end{array}$ \\
\hline People Risk & $\begin{array}{l}\text { Employment, health and } \\
\text { safety }\end{array}$ & $\begin{array}{l}\text { - Employee actions } \\
\text { - Compensation disputes } \\
\text { - Employee defection } \\
\text { - Labor disputes } \\
\text { - Strikes } \\
\text { - Employee illness } \\
\text { - Employee injury } \\
\text { - Forced retirement } \\
\text { - Promotions related disputes } \\
\text { - Discrimination and harassment } \\
\text { issues } \\
\text { - Infliction of distress }\end{array}$ \\
\hline People Risk & Internal fraud & $\begin{array}{l}\text { - Embezzlement } \\
\text { - Money laundering } \\
\text { - Unauthorized fund transfers } \\
\text { - Accounting fraud } \\
\text { - Credit card fraud } \\
\text { - Tax fraud }\end{array}$ \\
\hline People Risk & Trading misdeeds & $\begin{array}{l}\text { - Insider trading } \\
\text { - Market manipulation } \\
\text { - Improper pricing } \\
\text { - Unauthorized trading }\end{array}$ \\
\hline
\end{tabular}


Table 5.2 (Continued)

\begin{tabular}{|c|c|c|}
\hline Risk & Category & Examples \\
\hline Process Risk & Errors and omissions & $\begin{array}{l}\text { - Employee error } \\
\text { - Inadequate quality control } \\
\text { - Inadequate security } \\
\text { - Inadequate supervision } \\
\text { - Failure to file a proper report }\end{array}$ \\
\hline Process Risk & $\begin{array}{l}\text { Transaction and business } \\
\text { process risk }\end{array}$ & $\begin{array}{l}\text { - Inadequate account } \\
\text { reconciliation } \\
\text { - Inadequate transaction } \\
\text { completion } \\
\text { - Inadequate transaction execution } \\
\text { - Inadequate transaction } \\
\text { settlement } \\
\text { - Lack of proper due diligence } \\
\text { - Loss of critical information }\end{array}$ \\
\hline Technology Risk & $\begin{array}{l}\text { General technology } \\
\text { problems }\end{array}$ & $\begin{array}{l}\text { - New technology failure } \\
\text { - Technology-related operational } \\
\text { errors }\end{array}$ \\
\hline Technology Risk & Hardware & $\begin{array}{l}\text { - System failure } \\
\text { - Outdated hardware }\end{array}$ \\
\hline Technology Risk & Security & $\begin{array}{l}\text { - Computer virus } \\
\text { - Data security } \\
\text { - Hacking }\end{array}$ \\
\hline Technology Risk & Software & $\begin{array}{l}\text { - Inadequate testing } \\
\text { - System failure } \\
\text { - Incompatible software }\end{array}$ \\
\hline Technology Risk & Systems & $\begin{array}{l}\text { - Inadequate systems } \\
\text { - System maintenance }\end{array}$ \\
\hline Technology Risk & Telecommunications & $\begin{array}{l}\text { - Fax } \\
\text { - Internet } \\
\text { - E-mail } \\
\text { - Telephone }\end{array}$ \\
\hline External Risk & External fraud & $\begin{array}{l}\text { - Burglary } \\
\text { - External misrepresentation } \\
\text { - External money laundering } \\
\text { - Robbery }\end{array}$ \\
\hline External Risk & Natural disasters & $\begin{array}{l}\text { - Flooding } \\
\text { - Hurricane } \\
\text { - Blizzard } \\
\text { - Earthquake }\end{array}$ \\
\hline External Risk & Non-natural disasters & $\begin{array}{l}\text { - Arson } \\
\text { - Bomb threat } \\
\text { - Explosion } \\
\text { - Plane crashes } \\
\text { - War }\end{array}$ \\
\hline
\end{tabular}




\subsection{FREQUENCY AND SEVERITY OF LOSS EVENTS}

Operational risk events can be divided into high-frequency, low-severity events (which occur regularly) and low-frequency, high-severity events (which are rare but produce huge losses if they occur). The low-frequency, high-severity risks (such as internal fraud, which could jeopardize the whole future of the firm) are risks associated with loss events that lie in the very upper tail of the total loss distribution. High-frequency, low-severity risks (such as credit card fraud and some human risks) have high expected loss but relatively low unexpected loss.

The BCBS (2002b) has produced results on the frequency and severity of each type of risk event for a typical bank with investment, commercial, and retail operations. These are reported in Table 5.3, showing that internal fraud is a low-frequency, high-severity risk event. These are the kinds of event that can bring a major bank to its knees (for example, the Barings case). It is also shown that external fraud is less severe than internal fraud although it is more frequent. Damage to physical assets, on the other hand, is a low-frequency, low-severity event and so is business disruption and system failure. Exactly the opposite to internal fraud is execution, delivery, and process management, which is a high-frequency, low-severity event.

The frequency and severity of operational loss events depend on and vary with the business line, as shown in Table 5.4. For example, internal fraud is a low-frequency, high-severity event in corporate finance, trading and sales, commercial banking, and asset management, but it is a low-frequency, medium-severity event in retail banking, payment and settlement, and in agency and custody. Execution, delivery, and process management is a low-frequency, low-severity event in corporate finance, but it is a highfrequency, low-severity event in trading and sales, retail banking, and in payment and settlement. It is also a medium-frequency, low-severity event in commercial banking, agency and custody, and asset management.

Table 5.3 Frequency and severity of operational risk events

\begin{tabular}{lcc}
\hline Risk Event & Frequency & Severity \\
\hline Internal fraud & $\mathrm{L}$ & $\mathrm{H}$ \\
External fraud & $\mathrm{H} / \mathrm{M}$ & $\mathrm{L} / \mathrm{M}$ \\
Employment practices and workplace safety & $\mathrm{L}$ & $\mathrm{L}$ \\
Clients, products, and business practices & $\mathrm{L} / \mathrm{M}$ & $\mathrm{H} / \mathrm{M}$ \\
Damage to physical assets & $\mathrm{L}$ & $\mathrm{L}$ \\
Business disruption and system failures & $\mathrm{L}$ & $\mathrm{L}$ \\
Execution, delivery, and process management & $\mathrm{H}$ & $\mathrm{L}$ \\
\hline
\end{tabular}




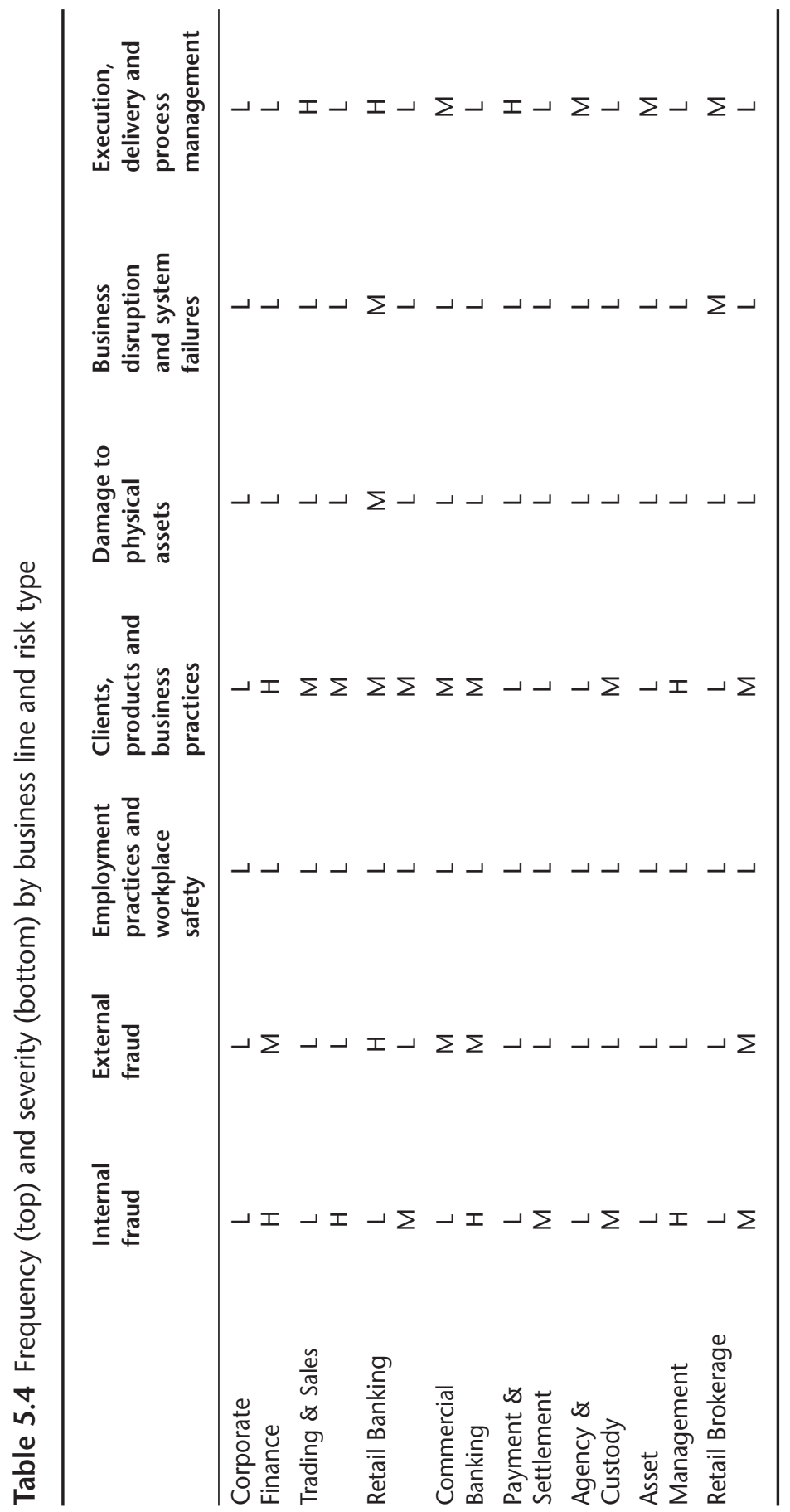


Based on the frequency of loss events, Pezier (2003a) classifies operational risk into nominal, ordinary, and exceptional risks. Nominal operational risk is the risk of repetitive losses (say, losses that may occur on average once a week or more frequently) associated with an ongoing activity such as settlement risk, minor external fraud (credit cards), or human error in transaction processing. Ordinary operational risk is the risk of less frequent (say, between once a week and once every generation) but larger losses, yet not life-threatening for the firm. Exceptional operational risk produces losses that have no more than a few percent chance of occurrence over a year, but those losses may be life-threatening.

Examples of exceptional risk events are reported in Table 5.5. The majority of the institutions listed in the table went bankrupt, were taken over, or they

Table 5.5 Examples of exceptional operational loss events

\begin{tabular}{|c|c|c|}
\hline Year & Company & Cause of Loss \\
\hline 1991 & Salomon Brothers (U.S.) & $\begin{array}{l}\text { Treasury bond primary market } \\
\text { manipulation }\end{array}$ \\
\hline 1993 & $\begin{array}{l}\text { Bank of Commerce and Credit } \\
\text { International }(\mathrm{BCCl}) \\
\text { (Luxembourg) }\end{array}$ & Illegal activities (drugs, arms) \\
\hline 1994 & Kidder Peabody (U.S.) & Management Incompetence \\
\hline 1995 & Barings Bank (U.K.) & $\begin{array}{l}\text { Rogue trading and management } \\
\text { incompetence }\end{array}$ \\
\hline 1995 & Diawa Securities (Japan) & Involvement with gangsters \\
\hline 1996 & Bankers Trust (U.S.) & $\begin{array}{l}\text { Selling products that clients did } \\
\text { not fully understand }\end{array}$ \\
\hline 1997 & Morgan Grenfell (U.K.) & $\begin{array}{l}\text { Unauthorized investment in } \\
\text { illiquid assets }\end{array}$ \\
\hline 1997 & NatWest Markets (U.K.) & Mispricing of derivatives \\
\hline 1998 & $\begin{array}{l}\text { Long-Term Capital } \\
\text { Management (U.S.) }\end{array}$ & $\begin{array}{l}\text { Lack of transparency, conflict of } \\
\text { interest, model bias and } \\
\text { uncontrolled leverage }\end{array}$ \\
\hline 2000 & $\begin{array}{l}\text { Equitable Life Assurance } \\
\text { Society (U.K.) }\end{array}$ & $\begin{array}{l}\text { Non-respect of guaranteed } \\
\text { annuity contracts }\end{array}$ \\
\hline 2001 & $\begin{array}{l}\text { Cantor Fitzgerald and } \\
\text { Others (U.S.) }\end{array}$ & $\begin{array}{l}\text { Terrorist attack on World Trade } \\
\text { Center }\end{array}$ \\
\hline 2002 & Allied Irish Bank (U.S.) & Rogue trading \\
\hline 2002 & Merrill Lynch (U.S.) & Biased analyst recommendations \\
\hline 2003 & Central Bank of Iraq (Iraq) & $\begin{array}{l}\text { External fraud (by the former } \\
\text { President) }\end{array}$ \\
\hline 2004 & Yukos Oil Company (Russia) & Internal fraud \\
\hline 2005 & Central Bank of Brazil (Brazil) & $\begin{array}{l}\text { External fraud (a brilliantly- } \\
\text { executed bank robbery) }\end{array}$ \\
\hline 2006 & Royal Bank of Scotland (U.K.) & External fraud \\
\hline
\end{tabular}


were forced to merge as a consequence of their losses (hence the characteristic of life-threatening loss events). These were all consequences of deliberate actions and not mere accidents. In most cases, these actions were unethical, illegal, or criminal. They were not necessarily initiated by senior management but they were at least allowed to endure by management incompetence and/or negligence. The root problem is individual or corporate greed. These loss events have been widely publicized and used as case studies.

Sometimes, of course, it may not be clear whether the failure of a firm is due to operational risk only or a multiplicity of risks (recall the discussion in Chapter 4 on distinguishing operational loss events from market and credit loss events). Take, for instance, the case of the most publicized hedge fund failures during the period 1994-2002, which are shown in Figure 5.1. These failures brought total losses of $\$ 12.8$ billion caused by a variety of factors, as shown in Table 5.6. As we can see, the failure of the ten hedge funds is attributed to more than operational risk, but it is the diversity of operational risk that makes it appear more prominently in Table 5.6. In a Capco Research (2002) paper, these failures were attributed mostly (50 percent) to operational risk, followed by investment risk (38 percent) then business risk (6 percent) and multiple risks (6 percent). Presumably investment risk here means market risk and credit risk. Although one tends to think that market risk would be more important

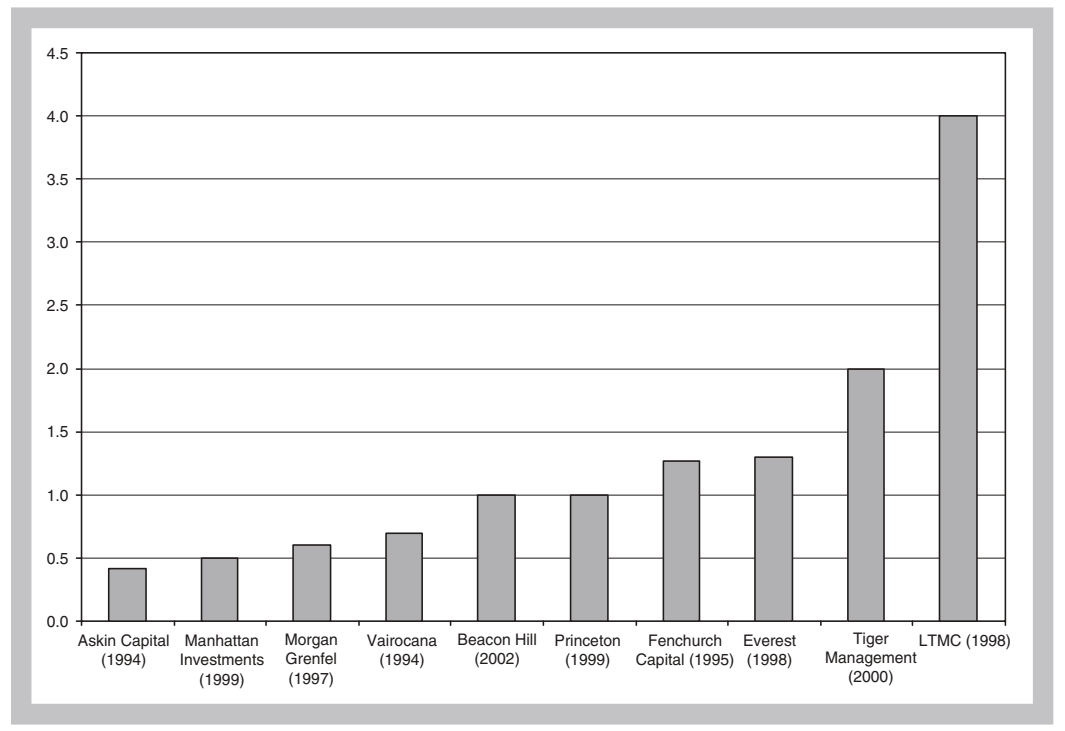

Figure 5.1 Losses incurred in the ten most publicized hedge fund failures (\$billion) 
Table 5.6 The risk factors responsible for hedge fund failures

\begin{tabular}{lcc}
\hline Market Risk Factors & Credit Risk Factors & Operational Risk Factors \\
\hline - Trading losses & - Post-Russian & - Weakness in the risk \\
- Directional bets & debt-default shock & management systems \\
- Highly complex portfolios & & - Misrepresentation of \\
- Unfavorable market & fund performance \\
- conditions & - Unauthorized holdings \\
- High and uncontrolled & of unlisted securities \\
leverage & - Pricing irregularities \\
& - Lack of liquidity \\
& - Conflict of interest \\
& - Collusion with a prime \\
& broker \\
& - Absence of adequate risk \\
& management system for \\
& new strategies \\
& - Lack of transparency to \\
& prime broker \\
& Model bias in the risk \\
& management process \\
\hline
\end{tabular}

than operational risk in the case of hedge funds, this is obviously not the case here. Thus, the prominence of operational risk in Table 5.6 is not only due to its diversity but also to the fact that the failures are attributed mostly to operational risk.

\subsection{A CLOSE LOOK AT OPERATIONAL LOSS FIGURES}

To get a feel of the frequency and severity of operational loss events, we examine the loss data reported in BCBS (2003c) as a result of the 2002 data collection exercise. The BCBS asked participating banks to provide information on operational losses in 2001. A total of 89 banks participated in this exercise, reporting the number of loss events and the amounts involved (in millions of euros). The reported losses were classified by business lines and event types according to the BCBS's classification, but some reported losses were unclassified. As far as the number of losses is concerned, a total of 47,269 events were reported, 43 percent of which were events of external fraud (Figure 5.2) and more than 60 percent were in retail banking (Figure 5.3). As far as the loss amount is concerned, the total amount lost was EUR7.8 billion, 29 percent of which came under execution, delivery, and process management (Figure 5.4) and 290 percent was under retail banking and commercial banking (Figure 5.5). In terms of business line/event type combinations, the most frequent losses occurred 


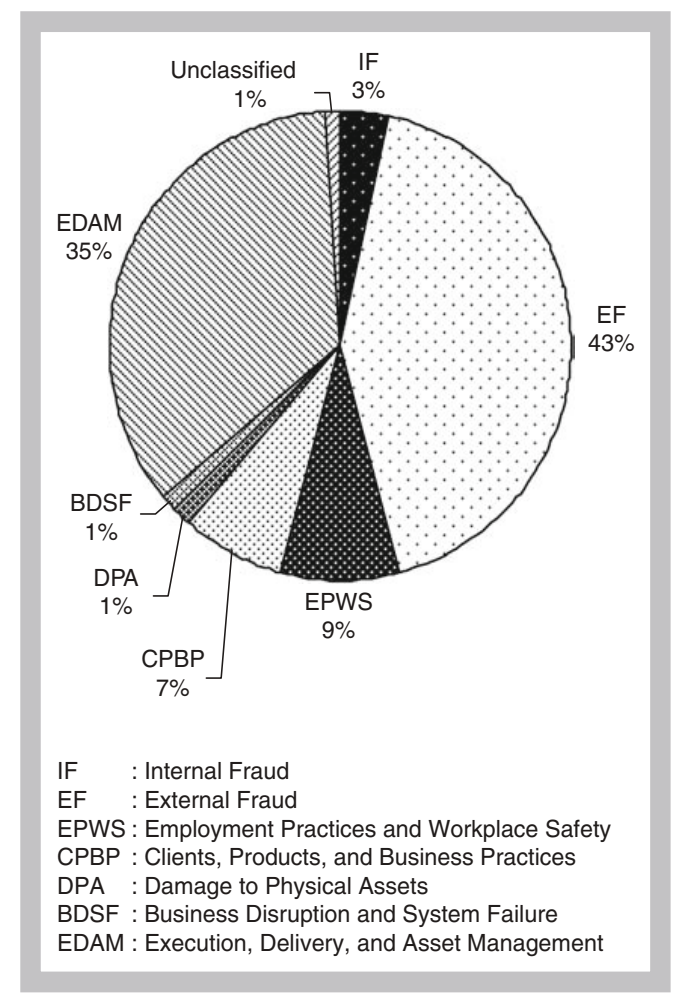

Figure 5.2 Number of losses by event type (the BCBS (2003c) data)

in external fraud in retail banking, whereas the largest loss amounts occurred in damage to physical assets in commercial banking.

Switching now to the concepts of frequency and severity, the frequency is the number of loss events, whereas average severity can be calculated by dividing the total loss incurred under a certain loss event type or business line by the corresponding number of losses. Figures 5.6 and 5.7 report the severity of losses by event type and business line, respectively.

The operational loss events reported in Table 5.4 encompass mostly financial institutions. But all entities are exposed to operational risk in the course of their daily business, and for this reason, it may be useful to examine some operational risk events that span a wide variety of entities. Appendix 5.1 contains a table showing 62 randomly selected operational loss events that took place between 1984 and 2006. The reported operational losses were incurred by banks (including central banks), non-bank financial institutions, and firms operating in various sectors (manufacturing, utilities, transportation, food, mining, and entertainment), as well as universities, cities, and 


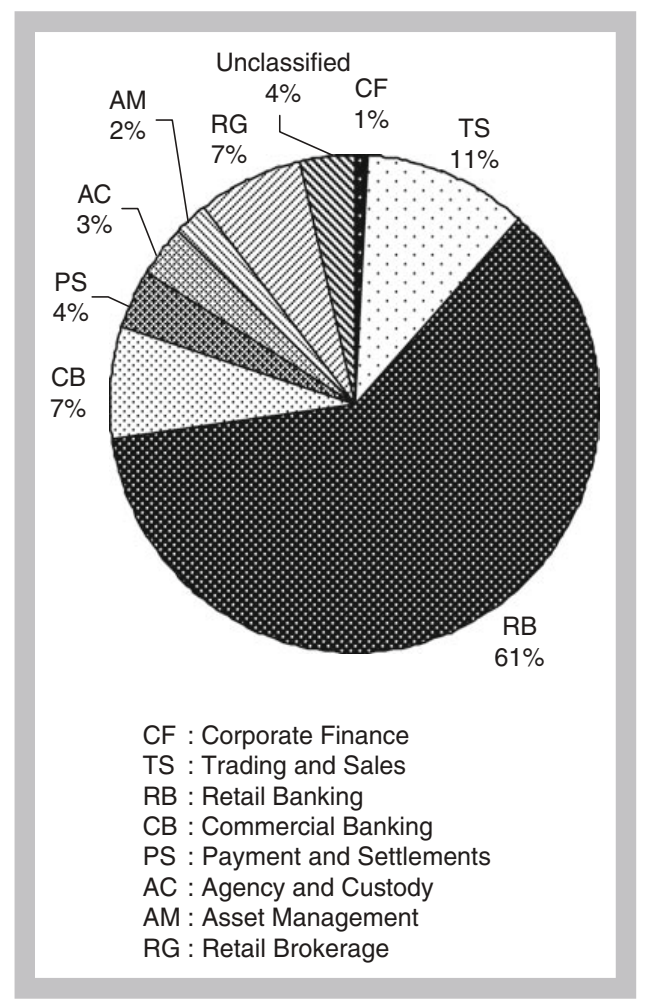

Figure 5.3 Number of losses by business line (the BCBS (2003c) data)

government entities. Because the BCBS's classification of operational loss events covers banks only, a large number of loss events appear as unclassified. The losses reported in the table range between the $\$ 9499$ dollar incurred by the Yorkshire Building Society (as a result of an alleged sex discrimination case) and the $\$ 95$ billion incurred by New York City as a result of the $9 / 11$ terrorist attacks.

Table 5.7 shows a classification of the 62 events by type and business line, providing information on the number of events, the mean and the median values of the loss incurred, as well as the smallest and largest loss in each case. By event type, the most serious events (measured by the mean value of the loss) are damage to physical assets and internal fraud, with the former appearing more important because of the losses incurred by New York City as a result of the $9 / 11$ attacks. By business line, the unclassified business lines are the ones where the big losses were incurred, this is mainly due to the fact that these losses were incurred by non-financial firms and other entities, which are not covered by the business line classification 


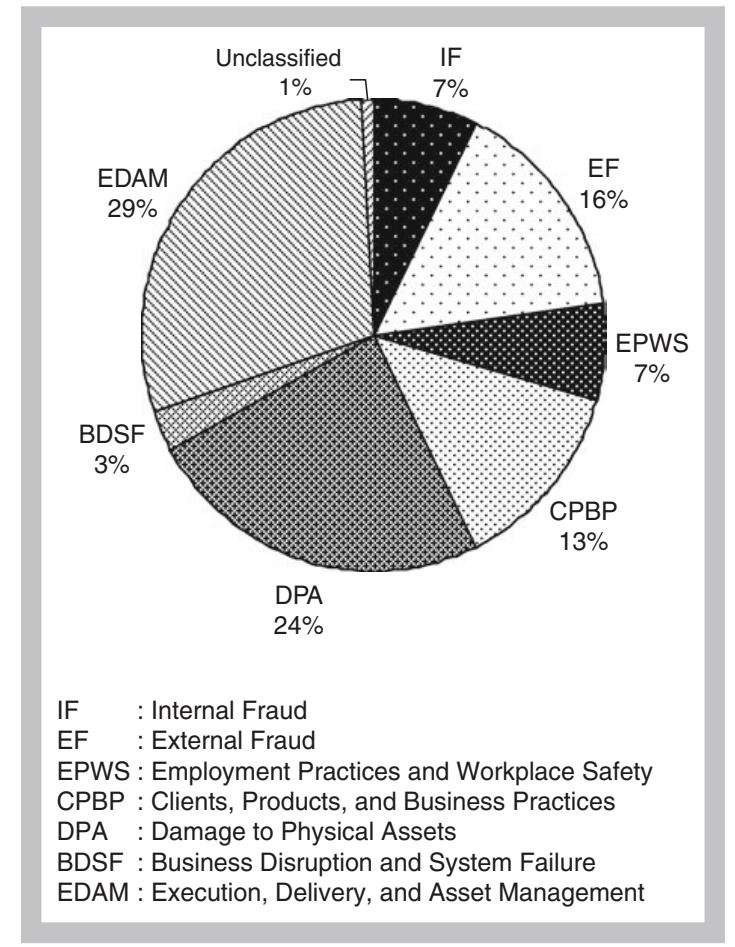

Figure 5.4 Loss amount by event type (the BCBS (2003c) data)

of the BCBS. Naturally, the judgment changes if we consider the median loss as opposed to the mean loss: in this case, for example, external fraud appears to be more serious than internal fraud. In terms of the number of events (frequency), events related to clients, products, and business practices are the most frequent followed by internal fraud.

Table 5.8 shows a two-way classification of the same loss events by type and business line. If we exclude the events recognised by the unclassified business lines, we can see that the most common combination are loss events related to clients, products and business practices in corporate finance followed by internal fraud in commercial banking. While these tables provide some interesting information, one has to be careful about deriving some overall conclusions from a relatively small sample of events.

Finally, Appendix 5.2 presents a brief description of loss events organized by event type and business line as reported by the media. This is just a drop in the ocean compared to the universe of operational loss events. Operational losses are indeed more frequent than what one may believe, which is definitely the impression one gets by examining operational loss databases. 


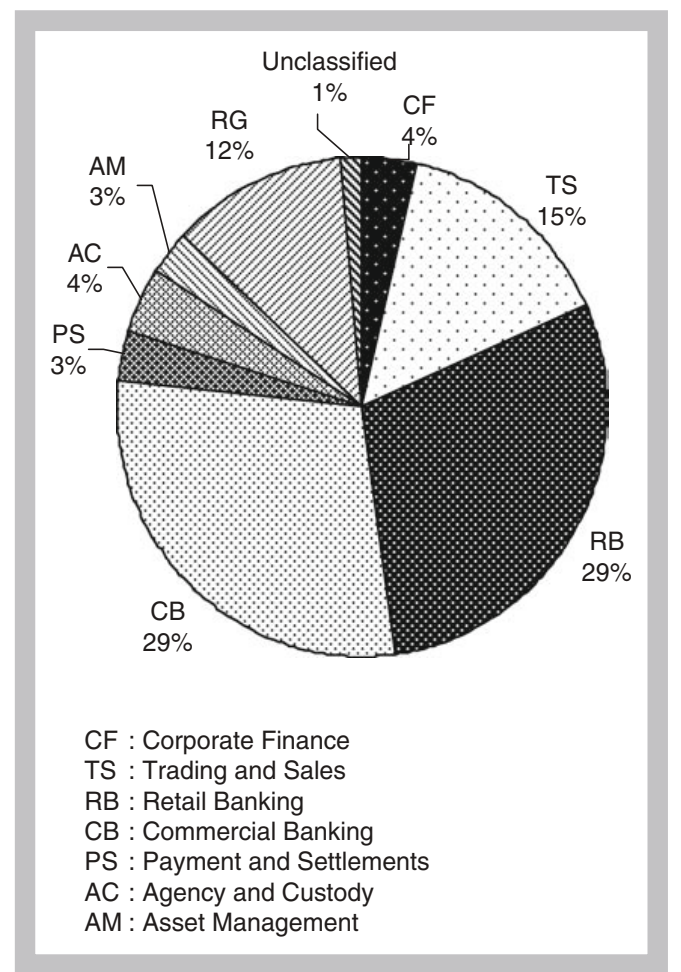

Figure 5.5 Loss amount by business line (the BCBS (2003c) data)

\subsection{EXTERNAL OPERATIONAL LOSS DATABASES}

In this section we deal with external databases as opposed to internal databases of individual firms (which we will deal with in the following section). External databases may take two forms. The first, such as the British Bankers Association's (BBA) database the global operational loss database (GOLD), is a contributory scheme where members contribute their own loss data in return for access to the loss data of other members, ending up with an industry-pooled database. The second type are the public databases that record publicly released loss events, including the databases of vendors such as OpRisk Analytics and OpVantage through the OpRisk Global Data and OpVar database, which are parts of the SAS Institute, Inc and a division of Fitch Risk Management, respectively. These vendors collect data from public sources, such as newspaper reports, court filings, and Securities and Exchange Commission (SEC) filings. As well as classifying losses by the Basel business line and causal type, the databases also include descriptive information on each loss event. A description of the GOLD database can be found on the BBA's website (www.bba.org.uk). 


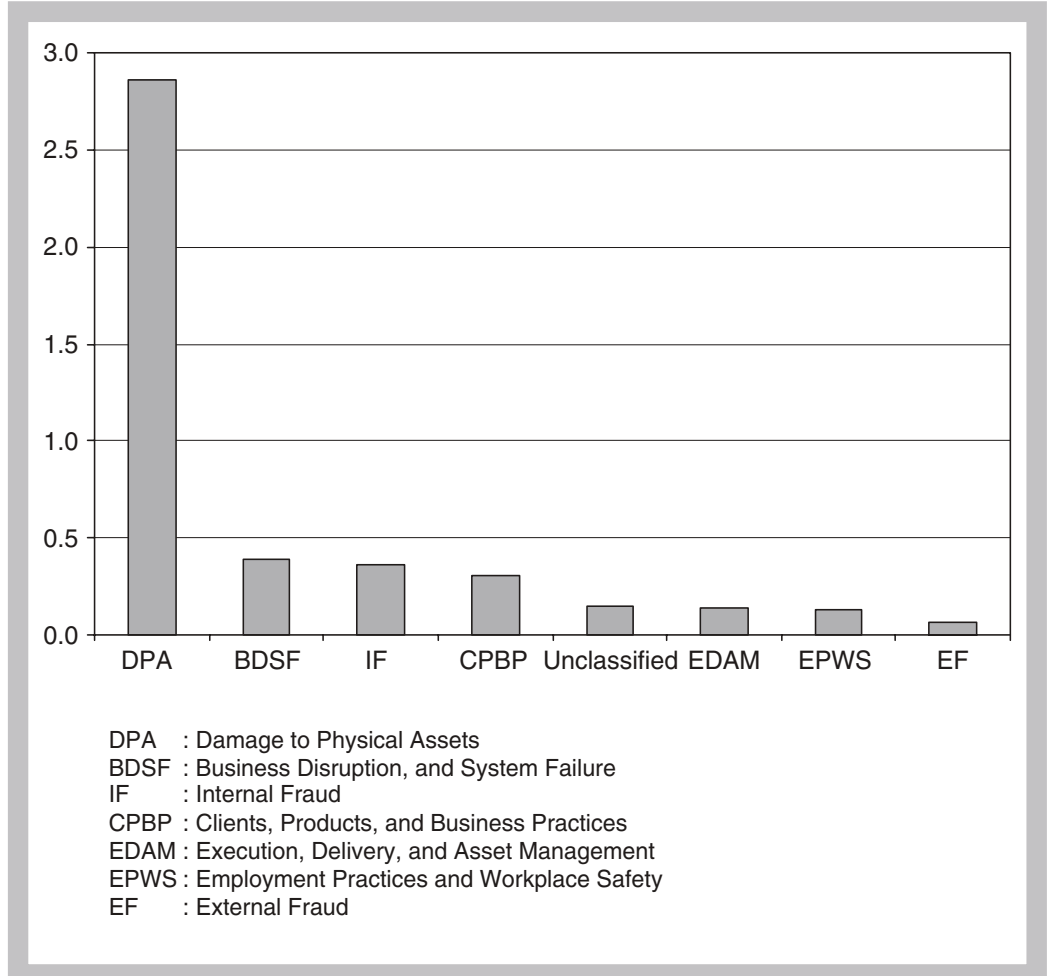

Figure 5.6 Severity by event type

Imeson (2006a) describes GOLD and similar databases by pointing out that these databases allow firms to consider the following questions: (i) What are typical loss events? (ii) Could loss circumstances occur in my firm? (iii) Would we see similar loss amounts? (iv) Which operational risks are subject to the highest losses? (v) How do loss events impact on the business? (vi) Which business areas suffer most losses? (vii) Are my controls or risk indicators appropriate? and (viii) Is reputational risk associated with loss events?

Baud, Frachot, and Roncalli (2002) identify two differences between the public databases and the industry-pooled databases, the first of which is the threshold for the recorded losses, as the threshold is expected to be much higher in the case of public databases than in the industry-pooled database. The second difference is the level of confidence one can place on the information provided by the database. For example, nothing ensures that the threshold declared by an industry-pooled database is the actual threshold, as banks are not necessarily prepared to uncover all losses above this threshold even though they pretend to do so. 


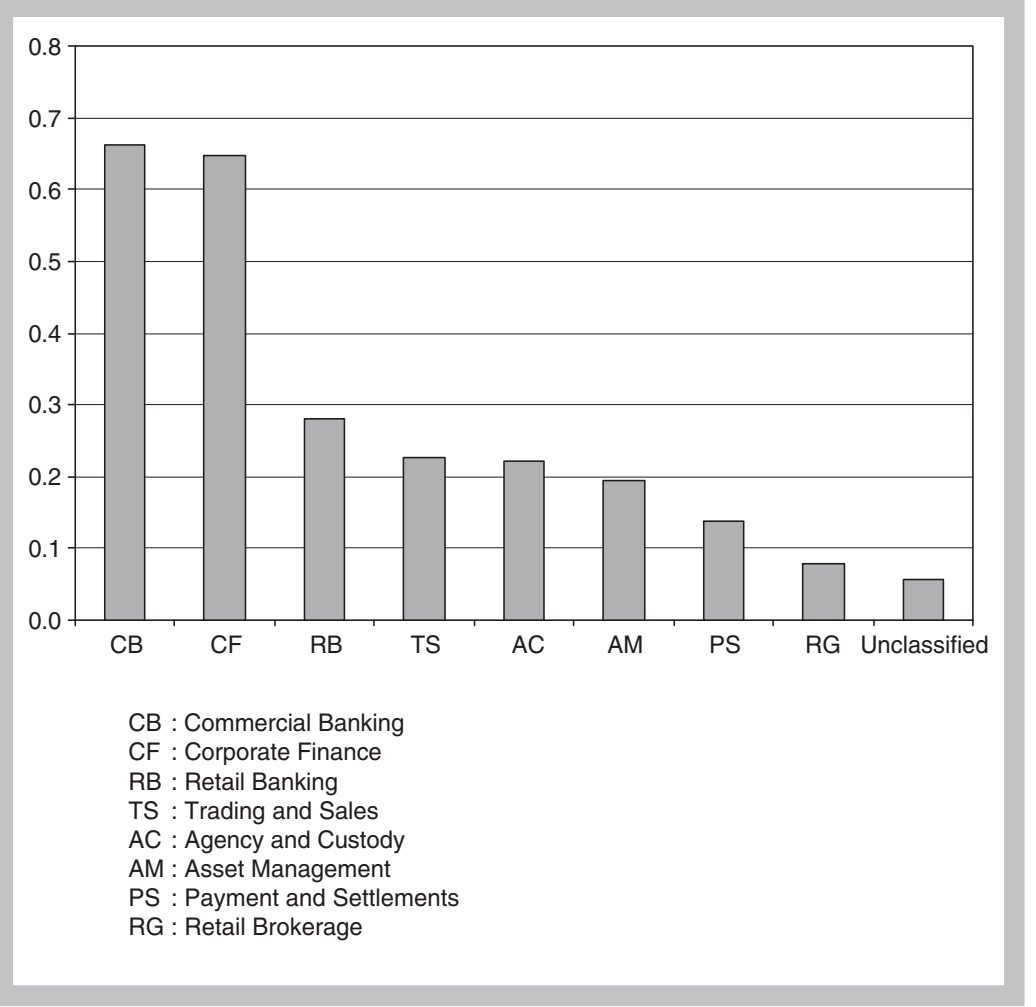

Figure 5.7 Severity by business line

An operational loss database must include, as a minimum, information on (i) the business line recognizing the loss; (ii) the unit in the business line recognizing the loss; and (iii) the function/process within the unit recognizing the loss. The information provided on each loss event include: (i) the firm incurring the loss; (ii) the amount; (iii) the start, end, and settlement dates; (iv) the type of entity incurring the loss; (v) the event type; and (vi) the business line. Also reported is a description of the event. Most of the information is obtained from the media.

Cagan (2001) argues that collecting data according to less optimal standards can misinform the decision-making process. Therefore, she recommends the following criteria for proper data collection:

Data must be collected according to the reasons for (sources of) the losses.

Data records should include contributory factors (such as the lack of controls), although these factors may not be the cause. This is because 
Table 5.7 Loss events (million dollars) by event type and business line (62 events)

\begin{tabular}{|c|c|c|c|c|c|}
\hline & Number & Mean & Median & Minimum & Maximum \\
\hline \multicolumn{6}{|l|}{ Event Type } \\
\hline Internal fraud & 15 & 677.0 & 9.1 & 0.38 & $9,300.0$ \\
\hline External fraud & 5 & 225.0 & 50.4 & 0.15 & $1,000.0$ \\
\hline $\begin{array}{l}\text { Employment } \\
\text { Practices and } \\
\text { Workplace safety }\end{array}$ & 7 & 17.2 & 1.2 & 0.95 & 100.0 \\
\hline $\begin{array}{l}\text { Clients, products } \\
\text { and business } \\
\text { practices }\end{array}$ & 22 & 72.9 & 8.3 & 0.44 & 925.0 \\
\hline $\begin{array}{l}\text { Damage to } \\
\text { physical assets }\end{array}$ & 9 & $10,700.0$ & 41.3 & 1.0 & $95,000.0$ \\
\hline $\begin{array}{l}\text { Business disruption } \\
\text { and system } \\
\text { failures }\end{array}$ & 1 & 175.0 & 175.0 & 175.0 & 175.0 \\
\hline $\begin{array}{l}\text { Execution, delivery } \\
\text { and process } \\
\text { management }\end{array}$ & 3 & 48.5 & 20.0 & 0.75 & 125.0 \\
\hline \multicolumn{6}{|l|}{ Business Line } \\
\hline Corporate Finance & 9 & 138.0 & 20.0 & 0.9 & 925.0 \\
\hline \multicolumn{6}{|l|}{ Trading \& Sales } \\
\hline Retail Banking & 2 & 7.5 & 7.5 & 0.01 & 15.0 \\
\hline $\begin{array}{l}\text { Commercial } \\
\text { Banking }\end{array}$ & 9 & 189.0 & 50.4 & 0.28 & $1,000.0$ \\
\hline $\begin{array}{l}\text { Payment \& } \\
\text { Settlement }\end{array}$ & 1 & 88.0 & 88.0 & 88.0 & 88.0 \\
\hline \multicolumn{6}{|l|}{$\begin{array}{l}\text { Agency \& } \\
\text { Custody }\end{array}$} \\
\hline $\begin{array}{l}\text { Asset } \\
\text { Management }\end{array}$ & 3 & 14.1 & 7.3 & 1.3 & 33.6 \\
\hline \multicolumn{6}{|l|}{ Retail Brokerage } \\
\hline Unclassified & 38 & 2.8 & 9.5 & 0.1 & $95,000.0$ \\
\hline
\end{tabular}

the contributory factors may intensify the severity of the loss. It was Leeson's activities that brought the demise of Barings, but inadequate supervision contributed to the severity of the loss. With adequate supervision, it is likely that his activities would have been put to an end at an earlier stage and a lower level of losses. 


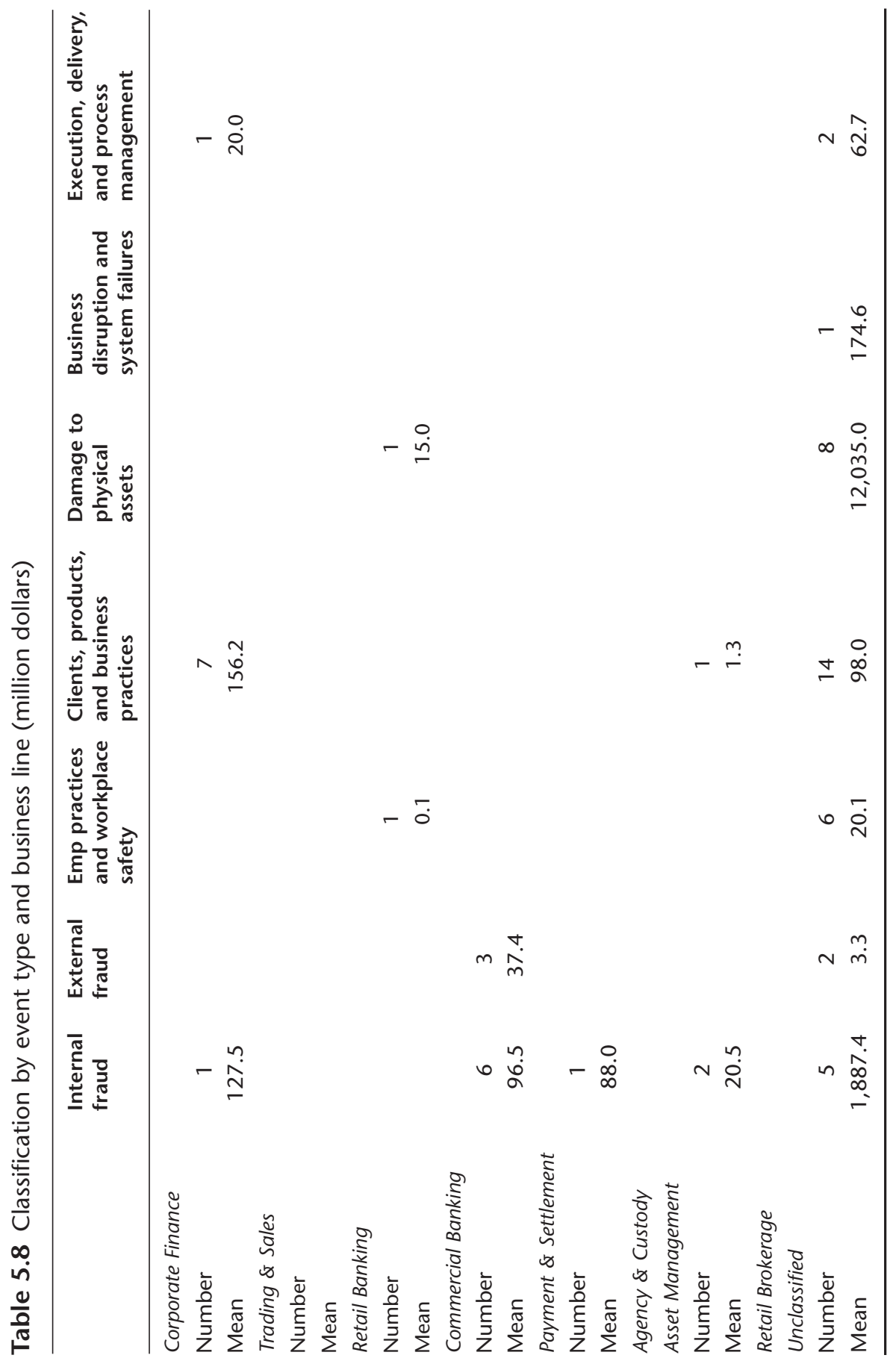


Each data record should include the type of loss incurred or the loss effect for the purpose of proper risk quantification.

Loss events should be tracked over their life cycles, as they are often not one-time events. This is why a database may show dates for the beginning, end, and settlement of loss events.

The scaling of data should be based on asset size "buckets" to avoid revealing the identity of the firm enduring operational loss.

Thrilwell (2003) describes how an operational loss database should be constructed and run with reference to the BBA's GOLD, where members of the BBA pool their operational loss data. The main driving force behind the willingness of banks to take part in this venture is their desire to benchmark their performance against their peers. In his analysis, Thirlwell talks about some general issues pertaining to the construction of an operational loss database, including confidentiality, anonymity, trust between participants, consistency, and flexibility/evolution. On the general issues he suggests the following:

1. The key factor in developing a database is confidentiality between the providers and the holder of the data.

2. Anonymity means that there are no clues that could trace a loss back to a particular participant unless the event is publicized in the media.

3. Trust is a fundamental factor if the participants are to report their loss events.

4. Consistency means that those reporting loss events should place similar losses in the same categories (that is, consistency in classification).

5. The database must be structured in such a way as to be easy to modify, should the need arise (for example, the emergence of new kinds of risk).

Thirlwell (2003) also talks about what he calls specific issues that include (i) operational loss versus operations loss; (ii) the classification of losses; (iii) the distinction between hard losses, soft losses, and near misses; (iv) the choice between cause/event and impact/event; (v) the reporting threshold; and (vi) scaling. On these issues he makes the following points:

1. Operational risk covers a far broader category of risk than simply operations risk (hence the distinction between operational risk and operations risk).

2. For the purpose of constructing a database, it is best to identify generic causes of losses since they can apply to a number of business activities. 
3. Soft losses, contingent losses, and near misses are excluded from the database because they are difficult to quantify.

4. The database should identify the number or size of the events that give rise to a loss, then the cause is identified by a narrative field.

5. Establishing a threshold for reporting is determined by two factors: the purpose of the database and the cost/benefit balance.

6. One bank's minor event is another bank's catastrophe, which requires some scaling factor, such as assets, transaction volume, income, expenses, etc.

While operational risk databases are a useful means of providing information, Thirlwell (2003) identifies some of their limitations, including the following:

1. The data are not independently audited.

2. The database does not provide information on the quality of controls in the reporting banks.

3. The choice of the reporting threshold affects the quantity of data reported.

4. There are some data reporting problems, including the double counting of operational risk, credit risk, and market risk, as well as some legal and other reasons that prevent reporting.

\subsection{INTERNAL OPERATIONAL LOSS DATABASES}

The Basel II Accord places significant emphasis on the construction of internal loss databases for the purpose of measuring and managing operational risk. The BCBS (2003a) stipulates that data on operational losses is a tool that can be used for validating risk estimates, being a component of risk reporting and a key input in any AMA model of operational risk. Cagan (2001) argues that internal databases resemble external databases in the sense that both need to be supported by a well-defined body of data standards, but they differ in the type of losses they cover. While internal databases record the high-frequency, low-severity losses that characterize daily operations, external databases tend to cover the low-frequency, high-severity losses.

Haubenstock (2004) argues that collecting operational loss data is more beneficial to the underlying bank than just the satisfaction of the regulatory requirements, including the very act of collecting the data and the calculation of regulatory capital. It is indeed a component of the risk management 
framework (see Chapter 8), which is implemented for the ultimate objective of reducing both the frequency and severity of operational losses. More specifically, Haubenstock (2004) lists the following advantages of operational loss data collection:

Increasing awareness of operational risk and its potential harm to the firm.

Quantifying exposure, which helps efforts to focus resources on risk mitigation where it is needed.

Analysis of the causes of events, which can be conducive to the improvement of controls.

Evaluating the self-assessment process, because actual loss events can be used as a quality check over self-assessment. For example, a department that endures 100 operational loss events with an average severity of $\$ 50,000$ cannot (without proper justification) make the prediction that it will only endure five loss events with an average severity of $\$ 10,000$ over the following year.

An important question that crops up in any endeavor to construct an operational loss database is what constitutes an operational loss event (that is, what to record and what to leave out). According to the Basel II Accord, only direct losses are to be recorded, which encompass categories ranging from the write-down of assets to the loss of physical assets. The justification for this restriction is that these effects are objective and can be measured directly and consistently. Just like the choice of the definition of operational risk, this choice is rather narrow for a pragmatic reason, to facilitate the measurement of operational risk and hence regulatory capital. However, Haubenstock (2004) argues that firms should define their own data collection policies, which may mean going beyond Basel II. As a matter of fact, some external databases go beyond the Basel II recommendations by recording events that are not recognized by the Accord for the purpose of calculating regulatory capital. Why? Because the collection of operational loss data has more benefits than the mere regulatory compliance, and because (as we will see in Chapter 8) it is an integral part of the operational risk management framework. Likewise, Cagan (2001) argues that although it makes sense to adopt a definition for quantifying capital that excludes items that cannot be easily calculated, it is important to collect softer and less quantifiable losses for the sake of qualitative analysis.

In addition to the direct losses identified by Basel II, Haubenstock (2004) recommends that firms should collect data on near misses, which are events where some type of failure occurred without incurring financial loss, and indirect losses (or associated costs), which include items like 
business interruption, forgone income, loss of reputation, and poor quality. He also recommends the inclusion of strategic or business risk events. We have already seen that the exclusion of business risk from the definition of operational risk is a controversial issue, which Haubenstock (2004) capitalizes upon in his defense of the inclusion of business risk. For example, he takes the difficulty of attributing the following costs to either operational risk or business risk to mean that the line between operational risk and strategic risk is not clear at all: pulling out of a country, a failed product introduction, restructuring costs after layoff and excess real estate capacity due to inaccurate estimation.

Another important issue is the determination of the loss threshold, which is the amount below which the underlying loss event will not be recorded. The answer is simply that the choice of a threshold is a matter of costs and benefits, which means that it should vary across firms and activities. Some guidance can be obtained from the external databases. For example, the Riskdata Exchange Association, the American Bankers Association, and the BBA use thresholds of $\$ 25,000, \$ 10,000$, and $\$ 50,000$, respectively. Roehr (2002) argues that the threshold, which is necessary to make the task of data collection manageable and cost effective, may change over time, depending on the business line and event type. He also argues that thresholds are likely to be much higher in external than in internal databases.

In addition to these issues, other related issues are confidentiality of the data and the mechanics of the collection process, including roles and responsibilities. We will have more to say about the modes of operational loss data collection in Chapter 8, so we close this chapter by saying a few words about confidentiality. In general, operational losses and events are regarded as very sensitive information, which means that there should be some standard for disclosure within and outside the firm. Firms, therefore, design their own confidentiality and data access restriction policies with the objective of striking a balance between security and transparency. 


\section{APPENDIX 5.1 SELECTED OPERATIONAL LOSS EVENTS}

Table 5A1.1 contains 62 randomly selected operational loss events organized chronologically, spanning the period 1984-2006. The table reports the settlement date (when the case is closed), the name of the entity incurring the loss, the loss amount in million US dollars, the business line and event type. When no specific business line appears $(-)$, this means that it is unclassified by the BCBS. This is because the BCBS classification is designed for banks only, whereas this table reports loss events endured by a variety of entities, including cities and universities. The source of information is various media outlets.

Table 5A1.1 Selected operational loss events reported by the media

\begin{tabular}{|c|c|c|c|c|}
\hline $\begin{array}{l}\text { Settlement } \\
\text { Date }\end{array}$ & Firm & $\begin{array}{c}\text { Loss } \\
\text { (US\$ million) }\end{array}$ & $\begin{array}{l}\text { Business } \\
\text { Line }\end{array}$ & Event Type \\
\hline 23/05/1984 & Nestle S.A. & 41.3 & - & Damage to Physical Assets \\
\hline $01 / 05 / 1988$ & $\begin{array}{l}\text { Nissan Motor } \\
\text { Company }\end{array}$ & 4.9 & - & $\begin{array}{l}\text { Clients, Products, and } \\
\text { Business Practices }\end{array}$ \\
\hline $12 / 07 / 1989$ & $\begin{array}{l}\text { Walt Disney } \\
\text { Company }\end{array}$ & 100.0 & - & $\begin{array}{l}\text { Employment Practices and } \\
\text { Workplace Safety }\end{array}$ \\
\hline $01 / 10 / 1990$ & Eastman Kodak & 92.5 & $\begin{array}{l}\text { Corporate } \\
\text { Finance }\end{array}$ & $\begin{array}{l}\text { Clients, Products, and } \\
\text { Business Practices }\end{array}$ \\
\hline $01 / 02 / 1991$ & $\begin{array}{l}\text { Mobil Oil } \\
\text { Company }\end{array}$ & 1.0 & - & $\begin{array}{l}\text { Clients, Products, and } \\
\text { Business Practices }\end{array}$ \\
\hline 20/12/1991 & $\begin{array}{l}\text { Apple } \\
\text { Computers }\end{array}$ & 19.8 & - & $\begin{array}{l}\text { Clients, Products, and } \\
\text { Business Practices }\end{array}$ \\
\hline 01/01/1992 & $\begin{array}{l}\text { Kuwait Oil } \\
\text { Tankers } \\
\text { Company }\end{array}$ & 100.0 & - & Internal Fraud \\
\hline $01 / 02 / 1992$ & Motorola Inc. & 15.1 & - & $\begin{array}{l}\text { Clients, Products, and } \\
\text { Business Practices }\end{array}$ \\
\hline $01 / 02 / 1992$ & Xerox Corp. & 2.5 & - & $\begin{array}{l}\text { Clients, Products, and } \\
\text { Business Practices }\end{array}$ \\
\hline $22 / 07 / 1992$ & Midland Bank & 6.0 & $\begin{array}{l}\text { Commercial } \\
\text { Banking }\end{array}$ & Internal Fraud \\
\hline 01/10/1992 & Caterpillar Inc. & 15.7 & - & $\begin{array}{l}\text { Employment Practices and } \\
\text { Workplace Safety }\end{array}$ \\
\hline $20 / 05 / 1993$ & Nippon Steel & 127.5 & $\begin{array}{l}\text { Corporate } \\
\text { Finance }\end{array}$ & Internal Fraud \\
\hline $01 / 07 / 1993$ & $\begin{array}{l}\text { Louisiana } \\
\text { Interstate Gas } \\
\text { Company }\end{array}$ & 35.0 & - & $\begin{array}{l}\text { Clients, Products, and } \\
\text { Business Practices }\end{array}$ \\
\hline $01 / 09 / 1993$ & $\begin{array}{l}\text { Yamaichi } \\
\text { Securities Co. }\end{array}$ & 96.0 & - & $\begin{array}{l}\text { Clients, Products, and } \\
\text { Business Practices }\end{array}$ \\
\hline 28/10/1993 & $\begin{array}{l}\text { Land Bank of } \\
\text { Taiwan }\end{array}$ & 4.0 & $\begin{array}{l}\text { Commercial } \\
\text { Banking }\end{array}$ & Internal Fraud \\
\hline
\end{tabular}


Table 5A1.1 (Continued)

\begin{tabular}{|c|c|c|c|c|}
\hline $\begin{array}{l}\text { Settlement } \\
\text { Date }\end{array}$ & Firm & $\begin{array}{c}\text { Loss } \\
\text { (US\$ million) }\end{array}$ & $\begin{array}{l}\text { Business } \\
\text { Line }\end{array}$ & Event Type \\
\hline 01/01/1994 & British Gas & 1.2 & - & $\begin{array}{l}\text { Employment Practices } \\
\text { and Workplace } \\
\text { Safety }\end{array}$ \\
\hline 01/01/1994 & $\begin{array}{l}\text { Sao Paulo State } \\
\text { Electricity } \\
\text { Company }\end{array}$ & 1.0 & - & Damage to Physical Assets \\
\hline $01 / 02 / 1994$ & Air France & 131.5 & - & Damage to Physical Assets \\
\hline $01 / 02 / 1994$ & US Airways & 8.1 & - & Damage to Physical Assets \\
\hline 01/10/1994 & $\begin{array}{l}\text { Stanford } \\
\text { University }\end{array}$ & 3.2 & - & Internal Fraud \\
\hline 01/01/1995 & $\begin{array}{l}\text { Lockheed Martin } \\
\text { Corporation }\end{array}$ & 24.8 & - & Internal Fraud \\
\hline $10 / 03 / 1995$ & Kraft Foods Inc. & 75.3 & $\begin{array}{l}\text { Corporate } \\
\text { Finance }\end{array}$ & $\begin{array}{l}\text { Clients, Products and } \\
\text { Business Practices }\end{array}$ \\
\hline $01 / 12 / 1995$ & $\begin{array}{l}\text { University of } \\
\text { Wisconsin }\end{array}$ & 3.5 & - & Damage to Physical Assets \\
\hline 01/01/1996 & Coca-Cola & 2.0 & - & $\begin{array}{l}\text { Clients, Products, and } \\
\text { Business Practices }\end{array}$ \\
\hline $01 / 01 / 1996$ & $\begin{array}{l}\text { University of } \\
\text { California at } \\
\text { Berkley }\end{array}$ & 1.0 & - & $\begin{array}{l}\text { Employment Practices and } \\
\text { Workplace Safety }\end{array}$ \\
\hline 01/01/1996 & $\begin{array}{l}\text { Yorkshire Building } \\
\text { Society }\end{array}$ & 0.01 & $\begin{array}{l}\text { Retail } \\
\text { Banking }\end{array}$ & $\begin{array}{l}\text { Employment Practices and } \\
\text { Workplace Safety }\end{array}$ \\
\hline 08/03/1996 & Nike Inc. & 15.0 & - & $\begin{array}{l}\text { Clients, Products, and } \\
\text { Business Practices }\end{array}$ \\
\hline $31 / 12 / 1996$ & $\begin{array}{l}\text { Bangkok Bank of } \\
\text { Commerce }\end{array}$ & 88.0 & $\begin{array}{l}\text { Payment and } \\
\text { Settlement }\end{array}$ & Internal Fraud \\
\hline $01 / 02 / 1997$ & $\begin{array}{c}\text { Toyota Motor } \\
\text { Corporation }\end{array}$ & 200.0 & - & $\begin{array}{l}\text { Damage to Physical } \\
\text { Assets }\end{array}$ \\
\hline 01/01/1998 & $\begin{array}{l}\text { National } \\
\text { Mortgage Bank } \\
\text { of Greece }\end{array}$ & 4.0 & - & $\begin{array}{l}\text { Clients, Products and } \\
\text { Business Practices }\end{array}$ \\
\hline 01/01/1998 & PepsiCo Inc. & 2.4 & - & $\begin{array}{l}\text { Clients, Products, and } \\
\text { Business Practices }\end{array}$ \\
\hline $17 / 02 / 2000$ & Singapore Airlines & 9.1 & - & Internal Fraud \\
\hline $15 / 06 / 2000$ & $\begin{array}{l}\text { Amsterdam Stock } \\
\text { Exchange }\end{array}$ & 65.0 & $\begin{array}{l}\text { Corporate } \\
\text { Finance }\end{array}$ & $\begin{array}{l}\text { Clients, Products, and } \\
\text { Business Practices }\end{array}$ \\
\hline $11 / 09 / 2001$ & New York City & $95,000.0$ & - & $\begin{array}{l}\text { Damage to Physical } \\
\text { Assets }\end{array}$ \\
\hline $11 / 09 / 2001$ & $\begin{array}{l}\text { Zurich Financial } \\
\text { Services Group }\end{array}$ & 900.0 & - & $\begin{array}{l}\text { Damage to Physical } \\
\text { Assets }\end{array}$ \\
\hline
\end{tabular}


Table 5A1.1 (Continued)

\begin{tabular}{|c|c|c|c|c|}
\hline $\begin{array}{l}\text { Settlement } \\
\text { Date }\end{array}$ & Firm & $\begin{array}{c}\text { Loss } \\
\text { (US\$ million) }\end{array}$ & $\begin{array}{l}\text { Business } \\
\text { Line }\end{array}$ & Event Type \\
\hline $31 / 12 / 2001$ & $\begin{array}{l}\text { Agricultural } \\
\text { Development } \\
\text { Bank of China }\end{array}$ & 1.7 & $\begin{array}{l}\text { Commercial } \\
\text { Banking }\end{array}$ & Internal Fraud \\
\hline $11 / 02 / 2002$ & British Airways & 6.5 & - & External Fraud \\
\hline $31 / 10 / 2002$ & $\begin{array}{l}\text { Municipal Credit } \\
\text { Union of New } \\
\text { York City }\end{array}$ & 15.0 & Retail Banking & Damage to Physical Assets \\
\hline $19 / 03 / 2003$ & $\begin{array}{l}\text { Central Bank of } \\
\text { Iraq }\end{array}$ & $1,000.0$ & $\begin{array}{l}\text { Commercial } \\
\text { Banking }\end{array}$ & External Fraud \\
\hline $25 / 03 / 2003$ & Commerzbank & 33.6 & $\begin{array}{l}\text { Asset } \\
\text { Management }\end{array}$ & Internal Fraud \\
\hline $01 / 04 / 2003$ & Yale University & 0.15 & - & External Fraud \\
\hline $31 / 05 / 2003$ & $\begin{array}{l}\text { UK Inland } \\
\text { Revenue }\end{array}$ & 174.6 & - & $\begin{array}{l}\text { Business Disruption and } \\
\text { System Failure }\end{array}$ \\
\hline $28 / 08 / 2003$ & $\begin{array}{l}\text { Central Bank of } \\
\text { Sweden }\end{array}$ & 0.1 & - & $\begin{array}{l}\text { Employment Practices and } \\
\text { Workplace Safety }\end{array}$ \\
\hline $19 / 03 / 2004$ & Bank of India & 82.2 & $\begin{array}{l}\text { Commercial } \\
\text { Banking }\end{array}$ & Internal Fraud \\
\hline $05 / 07 / 2004$ & $\begin{array}{l}\text { Merchant Bank of } \\
\text { Central Africa }\end{array}$ & 19.0 & $\begin{array}{l}\text { Corporate } \\
\text { Finance }\end{array}$ & $\begin{array}{l}\text { Clients, Products, and } \\
\text { Business Practices }\end{array}$ \\
\hline $06 / 09 / 2004$ & $\begin{array}{l}\text { New Zealand } \\
\text { Stock Exchange }\end{array}$ & 0.44 & - & $\begin{array}{l}\text { Clients, Products, and } \\
\text { Business Practices }\end{array}$ \\
\hline $20 / 10 / 2004$ & $\begin{array}{l}\text { KPMG } \\
\text { International }\end{array}$ & 10.0 & - & $\begin{array}{l}\text { Clients, Products, and } \\
\text { Business Practices }\end{array}$ \\
\hline $20 / 12 / 2004$ & $\begin{array}{l}\text { Yukos Oil } \\
\text { Company }\end{array}$ & $9,300.0$ & - & Internal Fraud \\
\hline $31 / 12 / 2004$ & Bank of China & 485.0 & $\begin{array}{l}\text { Commercial } \\
\text { Banking }\end{array}$ & Internal Fraud \\
\hline $12 / 04 / 2005$ & $\begin{array}{l}\text { New York Stock } \\
\text { Exchange }\end{array}$ & 20.0 & $\begin{array}{l}\text { Corporate } \\
\text { Finance }\end{array}$ & $\begin{array}{l}\text { Execution, Delivery, and } \\
\text { Asset Management }\end{array}$ \\
\hline $10 / 05 / 2005$ & $\begin{array}{l}\text { Banca Nazionale } \\
\text { del Lavoro }\end{array}$ & 1.3 & $\begin{array}{l}\text { Asset } \\
\text { Management }\end{array}$ & $\begin{array}{l}\text { Clients, Products, and } \\
\text { Business Practices }\end{array}$ \\
\hline $18 / 05 / 2005$ & Morgan Stanley & 1.6 & $\begin{array}{l}\text { Corporate } \\
\text { Finance }\end{array}$ & $\begin{array}{l}\text { Clients, Products, and } \\
\text { Business Practices }\end{array}$ \\
\hline $08 / 08 / 2005$ & $\begin{array}{l}\text { Central Bank of } \\
\text { Brazil }\end{array}$ & 70.0 & $\begin{array}{l}\text { Commercial } \\
\text { Banking }\end{array}$ & External Fraud \\
\hline $29 / 08 / 2005$ & Lloyds of London & 300.0 & - & $\begin{array}{l}\text { Clients, Products, and } \\
\text { Business Practices }\end{array}$ \\
\hline $03 / 09 / 2005$ & $\begin{array}{l}\text { State Bank of } \\
\text { India }\end{array}$ & 0.3 & $\begin{array}{l}\text { Commercial } \\
\text { Banking }\end{array}$ & Internal Fraud \\
\hline $24 / 01 / 2006$ & Lloyds of London & 124.6 & - & $\begin{array}{l}\text { Execution, Delivery, and } \\
\text { Asset Management }\end{array}$ \\
\hline
\end{tabular}


Table 5A1.1 (Continued)

\begin{tabular}{|c|c|c|c|c|}
\hline $\begin{array}{l}\text { Settlement } \\
\text { Date }\end{array}$ & Firm & $\begin{array}{c}\text { Loss } \\
\text { (US\$ million) }\end{array}$ & $\begin{array}{l}\text { Business } \\
\text { Line }\end{array}$ & Event Type \\
\hline $15 / 03 / 2006$ & $\begin{array}{l}\text { Commonwealth } \\
\text { Bank of Australia }\end{array}$ & 7.3 & $\begin{array}{l}\text { Asset } \\
\text { Management }\end{array}$ & Internal Fraud \\
\hline $25 / 04 / 2006$ & British Petroleum & 2.4 & - & $\begin{array}{l}\text { Employment Practices and } \\
\text { Workplace Safety }\end{array}$ \\
\hline $12 / 07 / 2006$ & Bank of America & 0.75 & - & $\begin{array}{l}\text { Execution, Delivery, and } \\
\text { Asset Management }\end{array}$ \\
\hline $24 / 07 / 2006$ & $\begin{array}{l}\text { Credit Suisse First } \\
\text { Boston }\end{array}$ & 6.7 & $\begin{array}{l}\text { Corporate } \\
\text { Finance }\end{array}$ & $\begin{array}{l}\text { Clients, Products, and } \\
\text { Business Practices }\end{array}$ \\
\hline $24 / 07 / 2006$ & Lehman Brothers & 0.88 & $\begin{array}{l}\text { Corporate } \\
\text { Finance }\end{array}$ & $\begin{array}{l}\text { Clients, Products, } \\
\text { and Business Practices }\end{array}$ \\
\hline $02 / 08 / 2006$ & $\begin{array}{l}\text { Royal Bank of } \\
\text { Scotland }\end{array}$ & 50.4 & $\begin{array}{l}\text { Commercial } \\
\text { Banking }\end{array}$ & External Fraud \\
\hline
\end{tabular}

\section{APPENDIX 5.2 A DESCRIPTION OF SOME OPERATIONAL LOSS EVENTS BY TYPE AND BUSINESS LINE}

Tables 5A2.1 and 5A2.2 contain a brief description of selected loss events, as reported by the media, classified by event type and business line, respectively.

Table 5A2.1 A description of some operational loss events by type

\begin{tabular}{|c|c|c|}
\hline Event Type & Company & Description of Event \\
\hline $\begin{array}{l}\text { Internal Fraud } \\
\text { (Robbery) }\end{array}$ & $\begin{array}{l}\text { Westpac Banking } \\
\text { Corporation (Australia) }\end{array}$ & $\begin{array}{l}\text { A senior bank customer relations manager } \\
\text { stole more than AUD3.5 million between } \\
\text { February } 2003 \text { and December } 2004 \\
\text { from } 15 \text { customers' accounts. He was } \\
\text { arrested in July } 2006 \text { and charged } \\
\text { with obtaining money by deception } \\
\text { and several counts of signature } \\
\text { forgery. }\end{array}$ \\
\hline $\begin{array}{l}\text { Internal Fraud } \\
\text { (Tax Evasion) }\end{array}$ & $\begin{array}{l}\text { GlaxoSmithKline plc } \\
\text { (U.S.A.) }\end{array}$ & $\begin{array}{l}\text { In September } 2006 \text {, a settlement was } \\
\text { reached between the company and the } \\
\text { U.S. Internal Revenue Service, whereby the } \\
\text { Company agreed to pay } \$ 3.4 \text { billion to } \\
\text { settle a dispute over the taxation dealings } \\
\text { between the British parent company } \\
\text { and its U.S. subsidiary over the period } \\
1989-2005 \text {. }\end{array}$ \\
\hline $\begin{array}{l}\text { Internal Fraud } \\
\text { (Robbery) }\end{array}$ & $\begin{array}{l}\text { JP Morgan Chase \& Co } \\
\text { (U.S.A.) }\end{array}$ & $\begin{array}{l}\text { At a hearing in a U.S. federal court held on } 21 \\
\text { August } 2006 \text {, a former mailroom employee } \\
\text { pleaded guilty to the theft of some } \$ 100 \\
\text { million in corporate cheques from a lock-box } \\
\text { facility in New York. }\end{array}$ \\
\hline
\end{tabular}


Table 5A2.1 (Continued)

\begin{tabular}{|c|c|c|}
\hline Event Type & Company & Description of Event \\
\hline $\begin{array}{l}\text { Internal Fraud } \\
\text { (Credit Fraud) }\end{array}$ & $\begin{array}{l}\text { Agricultural Bank of } \\
\text { China (China) }\end{array}$ & $\begin{array}{l}\text { In June } 2006, \text { China's Audit Office } \\
\text { announced that it had discovered cases of } \\
\text { criminal activity and fraudulent loans } \\
\text { worth } 51.5 \text { billion yuan ( } \$ 6.45 \text { billion) at } \\
\text { the Agricultural Bank of China. }\end{array}$ \\
\hline $\begin{array}{l}\text { Internal Fraud } \\
\text { (Credit Fraud) }\end{array}$ & $\begin{array}{l}\text { Universal Corporation } \\
\text { (U.S.A.) }\end{array}$ & $\begin{array}{l}\text { In September 2006, a California court } \\
\text { ordered Universal Corporation to } \\
\text { pay two of its employees } \$ 25 \text { million in } \\
\text { compensation for retaliation against } \\
\text { them after they had reported fraudulent } \\
\text { insurance claims. }\end{array}$ \\
\hline $\begin{array}{l}\text { Internal Fraud } \\
\text { (Credit Fraud) }\end{array}$ & ANZ (Australia) & $\begin{array}{l}\text { In June } 2006 \text { charges were brought } \\
\text { against a former employee of the } \\
\text { ANZ following an investigation by the } \\
\text { Australian Securities and Investment } \\
\text { Commission into unauthorized loans totaling } \\
\text { AUD14.5 million. }\end{array}$ \\
\hline $\begin{array}{l}\text { External Fraud } \\
\text { (Robbery) }\end{array}$ & $\begin{array}{l}\text { Shanghai City Pension } \\
\text { Fund (China) }\end{array}$ & $\begin{array}{l}\text { A } 33 \text { year old Shanghai tycoon was arrested in } \\
\text { October } 2006 \text { following an investigation of } \\
\text { his role in the disappearance of } 3.2 \text { billion } \\
\text { yuan ( } \$ 400 \text { million) from the Shanghai City } \\
\text { Pension Fund. }\end{array}$ \\
\hline $\begin{array}{l}\text { Internal Fraud } \\
\text { (Robbery) }\end{array}$ & $\begin{array}{l}\text { Kuwait Oil Tankers } \\
\text { Company (Kuwait) }\end{array}$ & $\begin{array}{l}\text { In March 1992, two of four former executives } \\
\text { of the Kuwait Oil Tankers Company were } \\
\text { accused of embezzling } \$ 100 \text { million from the } \\
\text { state-owned company in the } 1980 \text { s and } \\
\text { during the 1990-91 Gulf crisis (war). }\end{array}$ \\
\hline $\begin{array}{l}\text { External Fraud } \\
\text { (Forgery) }\end{array}$ & $\begin{array}{l}\text { Macquarie Bank Limited } \\
\text { (Australia) }\end{array}$ & $\begin{array}{l}\text { In June } 2006 \text {, four people were charged over } \\
\text { Macquarie Bank's loss of about } \$ 4.5 \text { million } \\
\text { in margin loans obtained from the bank by } \\
\text { them on behalf of investors. }\end{array}$ \\
\hline $\begin{array}{l}\text { BDSF } \\
\text { (Hardware Failure) }\end{array}$ & $\begin{array}{l}\text { Sony Corporation } \\
\text { (Japan) }\end{array}$ & $\begin{array}{l}\text { In August 2006, Apple Computer and Dell Inc } \\
\text { recalled a total of } 5.9 \text { million notebook- } \\
\text { computer batteries made by Sony, which } \\
\text { can overheat and cause fire hazard. } \\
\text { The loss amount was estimated at } \\
\$ 225 \text { million. }\end{array}$ \\
\hline BDSF (Software) & Anthem Inc (U.S.A.) & $\begin{array}{l}\text { In November } 2005 \text {, the state government } \\
\text { of Kentucky ordered Anthem Inc to } \\
\text { refund } \$ 23.7 \text { million to customers } \\
\text { who were overcharged for Medicare } \\
\text { Supplement coverage as well as fining } \\
\text { it } \$ 2 \text { million. The company stated } \\
\text { that the faulty numbers resulted } \\
\text { from a computer processing error. }\end{array}$ \\
\hline BDSF (Software) & $\begin{array}{l}\text { National Australia Bank } \\
\text { (Australia) }\end{array}$ & $\begin{array}{l}\text { In November 2004, the National } \\
\text { Australia Bank announced that it had written } \\
\text { off AUD409 million in impaired software. }\end{array}$ \\
\hline
\end{tabular}


Table 5A2.1 (Continued)

\begin{tabular}{|c|c|c|}
\hline Event Type & Company & Description of Event \\
\hline BDSF (Software) & $\begin{array}{l}\text { ING Groep NV } \\
\text { (Netherlands) }\end{array}$ & $\begin{array}{l}\text { In June } 2005 \text {, the ING Groep NV announced } \\
\text { that it would compensate some } 500,000 \\
\text { customers who were provided with incorrect } \\
\text { calculations for personal insurance policies at } \\
\text { a cost of } 65 \text { million euros. }\end{array}$ \\
\hline BDSF (Systems) & $\begin{array}{l}\text { JPMorgan Chase \& Co } \\
\text { (U.S.A.) }\end{array}$ & $\begin{array}{l}\text { In 1998, Chase Manhattan Bank identified } \\
\text { inaccuracies in its bond recording system, } \\
\text { but nothing was done about it until it } \\
\text { merged with JP Morgan in } 2000 \text {. As a result, } \\
\text { the bank lost } \$ 46.8 \text { million as the glitch in } \\
\text { the system caused funds to be transferred to } \\
\text { bondholders who were not entitled to them. }\end{array}$ \\
\hline $\begin{array}{l}\text { EDPM (Data entry } \\
\text { or maintenance } \\
\text { errors) }\end{array}$ & $\begin{array}{l}\text { Universal Health Care } \\
\text { Services Inc. (U.S.A.) }\end{array}$ & $\begin{array}{l}\text { In August 2006, Universal Health Care Service } \\
\text { Inc announced that a U.S. government glitch } \\
\text { caused a hold up of members' promised } \\
\text { refunds, thus costing the company } \$ 3 \text { million. }\end{array}$ \\
\hline $\begin{array}{l}\text { EDPM (Failed } \\
\text { reporting } \\
\text { obligation) }\end{array}$ & $\begin{array}{l}\text { Morgan Stanley } \\
\text { (U.S.A.) }\end{array}$ & $\begin{array}{l}\text { In September 2006, the National Association } \\
\text { of Securities Dealers fined Morgan Stanley } \\
\$ 2.9 \text { million for a variety of trading and } \\
\text { trade-reporting violations over the period } \\
1999-2006 \text {. }\end{array}$ \\
\hline $\begin{array}{l}\text { EDPM (Inaccurate } \\
\text { reporting) }\end{array}$ & Banesto (Spain) & $\begin{array}{l}\text { In April 2001, a court case between Carlisle } \\
\text { Ventures and Banesto was settled when the } \\
\text { latter paid the former } \$ 13.5 \text { million in } \\
\text { compensation for false reporting. According } \\
\text { to Carlisle, Banesto portrayed itself as being } \\
\text { in a better financial position than it was in } \\
\text { reality. }\end{array}$ \\
\hline $\begin{array}{l}\text { EDPM (system } \\
\text { misoperation) }\end{array}$ & $\begin{array}{l}\text { Royal Bank of Canada } \\
\text { (Canada) }\end{array}$ & $\begin{array}{l}\text { In December 2005, the Royal Bank of Canada } \\
\text { announced that it would refund CAD25 } \\
\text { million to customers who were paid simple } \\
\text { rather than compound interest as a result of } \\
\text { a calculation error. }\end{array}$ \\
\hline $\begin{array}{l}\text { EPWS } \\
\text { (Discrimination) }\end{array}$ & $\begin{array}{l}\text { FedEx Corporation } \\
\text { (U.S.A.) }\end{array}$ & $\begin{array}{l}\text { In June } 2006 \text {, a court awarded two Lebanese- } \\
\text { American drivers } \$ 61 \text { million in damages for } \\
\text { suffering from racial discrimination by their } \\
\text { supervisor. }\end{array}$ \\
\hline EPWS (Loss of staff) & Benfield Group (U.K.) & $\begin{array}{l}\text { In October 2006, the Benfield Group (a } \\
\text { reinsurance brokerage firm) declared that its } \\
\text { results would be sharply worse than expected } \\
\text { due to the departure of key staff members. } \\
\text { The firm also declared that it would spend } \\
\text { some GBP10 million to retain the remaining } \\
\text { staff. }\end{array}$ \\
\hline $\begin{array}{l}\text { EPWS } \\
\text { (Termination } \\
\text { Issues) }\end{array}$ & Microsoft Corp. (U.S.A.) & $\begin{array}{l}\text { In October 2005, Microsoft paid } \$ 97 \text { million } \\
\text { to settle a lawsuit to compensate workers } \\
\text { who were employed and paid by temporary } \\
\text { agencies while they worked for Microsoft for } \\
\text { long periods. }\end{array}$ \\
\hline
\end{tabular}


Table 5A2.1 (Continued)

\begin{tabular}{|c|c|c|}
\hline Event Type & Company & Description of Event \\
\hline $\begin{array}{l}\text { EPWS } \\
\text { (Termination } \\
\text { Issues) }\end{array}$ & Commertzbank (U.K.) & $\begin{array}{l}\text { In November 2000, Commerzbank reached a } \\
\text { GBP5 million settlement with the former } \\
\text { chairman of a company that Commerzbank } \\
\text { had acquired. He was dismissed over a } \\
\text { dispute over the valuation of certain assets. }\end{array}$ \\
\hline $\begin{array}{l}\text { EPWS } \\
\text { (Discrimination) }\end{array}$ & $\begin{array}{r}\text { Merrill Lynch and } \\
\text { Company (U.K.) }\end{array}$ & $\begin{array}{l}\text { In July 2004, a former employee of Merrill } \\
\text { Lynch received a GBP550,000 compensation } \\
\text { from the employer following comments } \\
\text { about her physique and sex life at a } \\
\text { Christmas lunch. }\end{array}$ \\
\hline $\begin{array}{l}\text { DPA } \\
\text { (Natural Disasters) }\end{array}$ & $\begin{array}{l}\text { Murphy Oil Corporation } \\
\text { (U.S.A.) }\end{array}$ & $\begin{array}{l}\text { In August } 2005 \text {, Hurricane Katrina resulted in a } \\
\text { major leak in Murphy's oil refinery in } \\
\text { Louisiana, spilling over } 85,000 \text { barrels of oil. } \\
\text { The company had to pay } \$ 330 \text { million in } \\
\text { compensation to the residents of St Bernard } \\
\text { Parish in New Orleans. }\end{array}$ \\
\hline $\begin{array}{l}\text { DPA } \\
\text { (Natural } \\
\text { Disasters) }\end{array}$ & Allianz AG (Germany) & $\begin{array}{l}\text { In July 2002, Allianz AG declared losses of } 550 \\
\text { million euros as a result of severe flooding in } \\
\text { Europe that summer. }\end{array}$ \\
\hline $\begin{array}{l}\text { CPBP (Guideline } \\
\text { Violation) }\end{array}$ & $\begin{array}{l}\text { FleetBoston Financial } \\
\text { Corporation (U.S.A.) }\end{array}$ & $\begin{array}{l}\text { In October 2006, FleetBoston Financial } \\
\text { Corporation agreed to pay } \$ 19.75 \text { million for } \\
\text { failure to prevent the collapse of Enron } \\
\text { Corporation. }\end{array}$ \\
\hline $\begin{array}{l}\text { CPBP (Money } \\
\text { Laundering) }\end{array}$ & Bank of America & $\begin{array}{l}\text { In September } 2006 \text {, Bank of America agreed } \\
\text { to pay } \$ 7.5 \text { million to settle a money- } \\
\text { laundering case involving } \$ 3 \text { billion from } \\
\text { South America. }\end{array}$ \\
\hline $\begin{array}{l}\text { CPBP (Market } \\
\text { Practices) }\end{array}$ & $\begin{array}{l}\text { Deutsche Bank Group } \\
\text { (U.S.A.) }\end{array}$ & $\begin{array}{l}\text { In September 2006, Deutsche Asset } \\
\text { Management, a U.S. arm of Deutsche Bank, } \\
\text { agreed to pay } \$ 19.3 \text { million in settlement } \\
\text { after failure to disclose conflict of interest. }\end{array}$ \\
\hline
\end{tabular}

Table 5A2.2 A description of some operational loss events by business line

\begin{tabular}{|c|c|c|}
\hline Business Line & Company & Description of Event \\
\hline Corporate Finance & $\begin{array}{l}\text { JPMorgan Chase \& Co } \\
\text { (U.S.A.) }\end{array}$ & $\begin{array}{l}\text { In September 2006, the New York Stock } \\
\text { Exchange fined JPMorgan Chase } \\
\$ 400,000 \text { for violation of short-selling } \\
\text { rules. }\end{array}$ \\
\hline Corporate Finance & General Electric Co. (U.S.A.) & $\begin{array}{l}\text { In August 2006, General Electric paid } \\
\text { Canatxx Energy Ventures } \$ 136.1 \text { million } \\
\text { in damages for breaching a contract } \\
\text { pertaining to a joint industrial project. }\end{array}$ \\
\hline
\end{tabular}


Table 5A2.2 (Continued)

\begin{tabular}{|c|c|c|}
\hline Business Line & Company & Description of Event \\
\hline Corporate Finance & $\begin{array}{l}\text { Canadian Imperial } \\
\text { Bank of Commerce } \\
\text { (U.S.A.) }\end{array}$ & $\begin{array}{l}\text { In July 2006, the Canadian Imperial Bank of } \\
\text { Commerce agreed to pay } \$ 16.5 \text { million as } \\
\text { its share of the settlement over a case } \\
\text { involving the underwriting of securities } \\
\text { prior to the bankruptcy of Global Crossing } \\
\text { in January } 2002 \text {. }\end{array}$ \\
\hline Corporate Finance & Grand Tobidabo (Spain) & $\begin{array}{l}\text { In } 1994 \text { the former president of Grand } \\
\text { Tibidabo was arrested for } \\
\text { misappropriating } \$ 1 \text { billion pesetas from a } \\
\text { government-guaranteed loan to the } \\
\text { company received from Chase Manhattan } \\
\text { Bank. }\end{array}$ \\
\hline Commercial Banking & Bank Islam Malaysia (Malaysia) & $\begin{array}{l}\text { In 2005, Bank Islam Malaysia recorded } \\
\text { losses of } 480 \text { million ringgit due to higher } \\
\text { provisions for nonperforming loans made } \\
\text { on operations conducted by the bank's } \\
\text { offshore unit in Labuan. }\end{array}$ \\
\hline Commercial Banking & ABN Amro Bank (U.K.) & $\begin{array}{l}\text { In March } 1999, \text { ABN Amro declared losses } \\
\text { of } \$ 30 \text { million due to fraud related to } \\
\text { letters of credit. }\end{array}$ \\
\hline Retail Banking & $\begin{array}{l}\text { Wells Fargo \& Co. } \\
\text { (U.S.A.) }\end{array}$ & $\begin{array}{l}\text { In October 2006, Wells Fargo \& Co. } \\
\text { reached a } \$ 12.8 \text { million settlement in an } \\
\text { overtime pay lawsuit with employees. }\end{array}$ \\
\hline Retail Banking & Visa International (U.S.A.) & $\begin{array}{l}\text { In July 2006, Visa agreed to pay } \$ 100 \\
\text { million as its share of a settlement } \\
\text { regarding fees charged to cardholders for } \\
\text { foreign currency denominated } \\
\text { transactions. }\end{array}$ \\
\hline Retail Banking & ANZ (New Zealand) & $\begin{array}{l}\text { In March 2006, the ANZ pleaded guilty to } \\
45 \text { charges of breaching the new Zealand } \\
\text { Fair Trading Act by failing to disclose fees } \\
\text { charged for overseas currency transactions } \\
\text { on its credit cards. }\end{array}$ \\
\hline $\begin{array}{l}\text { Payment and } \\
\text { Settlement }\end{array}$ & Credit Lyonnais (Belgium) & $\begin{array}{l}\text { In March 1997, a former employee of } \\
\text { Credit Lyonnais Belgium was arrested for } \\
\text { embezzling BEF3.5 billion from the bank's } \\
\text { offices in Ghent. }\end{array}$ \\
\hline Agency Services & Dresdner Bank (U.K.) & $\begin{array}{l}\text { In July } 2004 \text {, Dresdner Bank was told by a } \\
\text { London court that it must repay EUR49.2 } \\
\text { million to the Saudi Arabia Monetary } \\
\text { Agency. }\end{array}$ \\
\hline
\end{tabular}

